\title{
FREE TRADE AND PROTECTIONISM
}

\author{
Benoni DIMULESCU, Ph.D. Candidate \\ University of Craiova
}

Key words: free trade, protectionism, tariff, quantitative restriction, subsidy

\begin{abstract}
One of the most interesting debates in economics is about free trade and protectionism. The arguments in favor of both directions are described by the analysis of free trade case and protectionism case. These are based on the economists' thoughts that, on a side, the state should not intervene in international flow of goods and services and, on another side, it should be created a system of tariffs, quotas and export subsidies in order to protect the national economy of each state in report with the foreign competition.
\end{abstract}

\section{The case for free trade}

\section{The incidence of tariffs}

A tariff causes a net loss for the economy, quantified in the next figure by the surface of two triangles ( $b$ and $d$ ). This loss is determined by the distortion of economic incentives both for producers and consumers. In contrast, the trend towards free trade excludes these distortions and leads to the increase of national welfare.

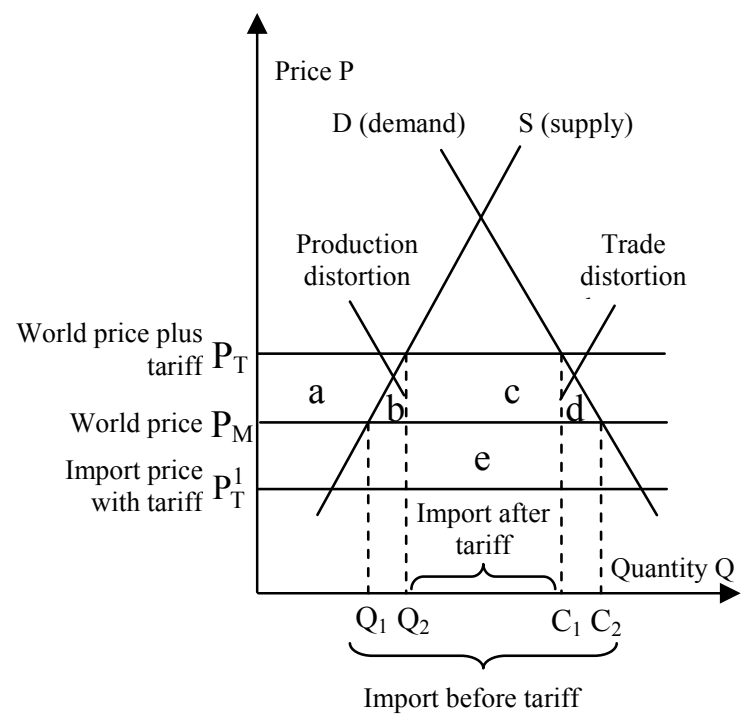

Figure 1: The tariff incidence

The tariff generates the growth of national production form $\mathrm{Q}_{1}$ to $\mathrm{Q}_{2}$, and advantages for the producer, while the national consumption decreases from $C_{2}$ to $C_{1}$, and creates disadvantages for consumers. It presumes the existence of a third player, the government, which wins from tariff revenues. Under these circumcises it occurs the question: what is the balance? Consumer loss $=\mathrm{a}+\mathrm{b}+\mathrm{c}+\mathrm{d}$; Producer gain $=\mathrm{a}$; 
Government revenue $=\mathrm{c}+\mathrm{e}$; Tariff net cost $=$ Consumer loss - Producer gain Government revenue, respectively $(a+b+c+d)-a-(c+e)=b+d-e$

There are two triangles (b and d), which surface means loss and a rectangle (e) which surface measure the gain. An effective way to analyze the gain and loss is the following: the triangles (b) and (d) represent efficiency loss that occurs because the tariff distort the insensitive for production and consumption, while the rectangle (e) reflects the gain for the terms of trade (the report between export prices and import prices), that appears as the tariff may lower the price of imports. This effect arises in the case of countries with a large share in word import that can demand to the exporters to decrease the prices after the tariff. If the importing country is a small one, in other words has an insignificant share in world import, it can't influence the decrease of import price, and the advantage for terms of trade disappear.

\section{The incidence of quantitative restriction}

A quantitative restriction (import quotas) limits the import to a certain quantity or value. Generally speaking it has the same effects as a tariff.

In the next example, the domestic price of importing country (Pi) is at a higher level than world price $\left(\mathrm{P}_{\mathrm{W}}\right)$. Also, it can be notice that the country applies import tariffs in addition to import quotas. We assume too that particular country does not have a relevant share in world import of restricted product.

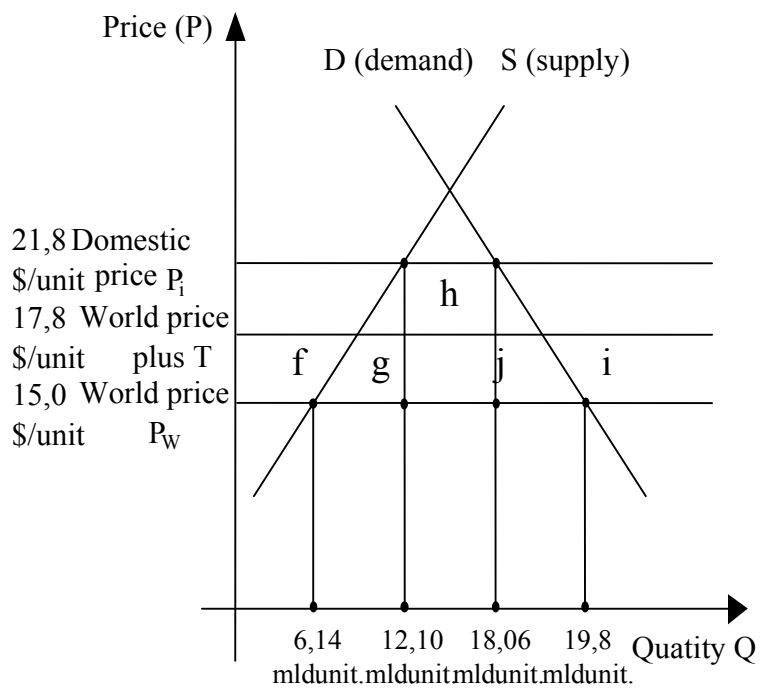

Figure 2: The incidence of quantitative restriction

The effect of the emergence of quantitative restriction is illustrated by five surfaces: $f, g, h, i$ and $j$. The producer gains due to do higher domestic prices $f$ surface. The consumer loses $\mathrm{f}+\mathrm{g}+\mathrm{h}+\mathrm{i}+\mathrm{j}$. The government gains from tariff revenues $\mathrm{j}$. The net effect of the introduction of a quantitative restriction is a loss $(\mathrm{f}+\mathrm{g}+\mathrm{h}+\mathrm{i}+\mathrm{j})-\mathrm{f}-$ $\mathrm{j}=\mathrm{g}+\mathrm{h}+\mathrm{i}$. From this net loss, $\mathrm{g}$ and $\mathrm{i}$ surfaces represent losses from import restriction and consumption restriction. The surface $\mathrm{h}$ is a rent accumulated by foreigners, a pure transfer abroad.

In the given example, in condition of free trade, the country import would be 13,04 milliard units $(19,18$ total consumption $-6,14$ domestic production). Under quotas, the 
import is restricted to 5,96 milliard units (18,06 consumption - 12,10 domestic production).

So, the import quotas increase domestic prices and production and generate additional incomes for foreigners that obtain the right to export in the country that introduced the restriction.

\section{The subsidy incidence}

Among the means used to stimulate the exports we take into consideration the export subsidy. The subsidy is direct, as an amount given to the exporter, representing the difference between the higher production cost and the lower world price, or indirect, such as reduction or exemption from the payment of profit tax or social contributions coincident to export merchandises.

When the governments offer subsidies, the producers will export the goods until the domestic price outweigh the external price with subsidy volume.

The effects of an export subsidy on prices are contrary to those of a tariff.

The price in exporting country increases from $\mathrm{P}_{\mathrm{W}}$ to $\mathrm{P}_{\mathrm{S}}$, but because in importing country the price decreases from $\mathrm{P}_{\mathrm{w}}$ to $\mathrm{P}$ ', the price rise is smaller than the subsidy.

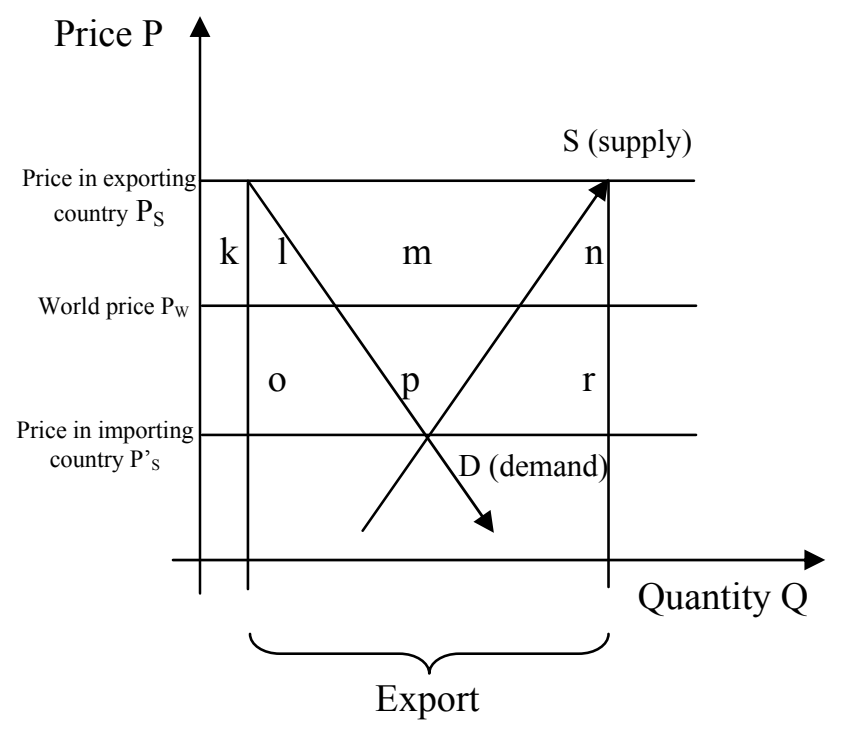

Figure 3: The subsidy incidence

In exporting country, the consumers lose, the producers gain, and the government lose as it spends money for subsiding. The consumer loss is in $k, 1$ surfaces. The producer gain is highlighted in $\mathrm{k}, 1, \mathrm{~m}$ surfaces. The government subsidy is in $\mathrm{k}, 1, \mathrm{~m}, \mathrm{n}$, $\mathrm{o}, \mathrm{p}, \mathrm{r}$ surfaces.

Consequently, the net effect is represented by the sum of $1, n, o, p, r$ surfaces. Among these, 1 and $\mathrm{n}$ are losses from production and consumption distortion, similar to those generated by tariff.

In addition and contrary to a tariff, an export subsidy worsen the terms of trade, by diminishing the export prices on external market from $\mathrm{P}_{\mathrm{W}}$ la $\mathrm{P}_{\mathrm{s}}$. This leads to the 
deterioration of the terms of trade $(o+p+r)=P_{W}-P^{\prime}{ }_{S}$ the quantity exported with subsidy. Therefore, an export subsidy produces for the whole country costs that prevail over benefits.

\section{Additional advantages}

The efficiency of the case for free trade is opposite to the cost-benefit analysis. A small country, by imposing a tariff, an import quota or by granting an export subsidy cannot influence the world price. Thus it has no advantages, but only disadvantages regarding production and consumption. Equally, the evolution towards free trade eliminates these distortions and maximizes national welfare.

Beside this basic argument, it is considered that the free trade brings about additional advantages.

First, the free trade allows the production concentration in large companies, generating economies of scale in production, instead of small enterprises with small production and less efficient, that would proliferate behind protection.

Secondly, the free trade offers to the entrepreneurs impetus to compete for export and with imports, to learn and to innovate, that doesn't happen in the case of "controlled trade", when the state impose the structure of imports and exports.

The third advantage is a general one, allowing to the government to step away from the interests of certain groups, to promote a policy of equal chances of all. Under protectionism policy, the government can be easily the prisoner of some interest groups. [Fota Constantin, 2004]

\section{The case for protectionism}

As has been stated above, the tariffs, the quantitative restrictions and the subsidies are likely to diminish the national and international welfare, apart from big countries that can improve their terms of trade, by removing the efficiency losses (production and consumption distortions). So, why all countries impose to imports tariff and nontariff barriers?

The answers to this question derive from the arguments formulated by governments and interest groups, which are displayed to the legislative bodies, when commercial policy measures are adopted. These arguments may be classified into four main categories: the use of monopoly power on the market for the improvement of terms of trade; in real world, the free trade leads to conditions different than optimum, and the import obstacles may rather increase than decrease the welfare; the tariffs, the quantitative restrictions and the subsidies may have social functions, mainly the redistribution of incomes and the raising of governmental revenues for public services; import restrictions may contribute to price and unemployment stabilization in situation of uncertainty and major fluctuations of demand, supply and international prices.

\section{The monopoly position}

It is true that a country with a large share in world import may influence the world prices by imposing a tariff and thus may improve its terms of trade.

The first problem that arises is: how high the tariff may be and, consequently, how considerable may be the gain of the country that imposed the tariff? As the American economist Harry Johnson demonstrated, if the tariff is prohibitive, the exporters will not be able to make price concessions indefinitely, as they would go bankrupt. In such a case, the import would cease and as a result would fade away the advantage from the terms of trade of importing country. So, the tariff would lose its goal. It results that the 
tariff should be imposed at a optimal level, which allows evenly the import of the country that introduced it and the export of partner countries.

The second problem is related to the response of exporting partner countries. As we illustrated above, the terms of trade of a country is the report between the prices of export goods and the prices of import goods. If the importing country, that imposed the tariff, gains from the diminishing of import price, the exporting country loses as its export price drops. At its turn, the exporting country may obviously impose a tariff in order to reduce its import price and to recover from the loss at export price. In this manner would lead to commercial wars. For this reason, it is reasonable that the countries do not apply unilateral tariff and nontariff barriers, except the case in which the lack of knowledge or the political situation in exporting country would hamper to react.

\section{Market failures}

In the price theory, the market failure is defined as the market process that causes the inefficient allocation of resources in an economy. When such market failures exist, the governmental intervention consisting in the imposing of tariff may determine in principle an efficient operation of economy and a growth of some person's welfare, without causing the decrease of other person welfare.

In this direction, the most used argument advocated by the German Friederich List and the American Alexander Hamilton, is known under the name of "infant industry". The power of this argument is that the tariff can be used temporary, as long as a new established industry requires protection from the competition of mature foreign companies. After ripening, the tariff may be eliminated; the country will have an industry with comparative advantages. Thus, all the countries will finally gain.

Also from theoretical point of view, this argument is persuasive, in real world some problems occur: the difficulty to identify the industries with a potential comparative advantage that will be protected; after the growth of an industry is very complicated politically to give up the protection; the social cost of protection and the gain from the industry development are extremely difficult to be measured, if not impossible, in order to determine the net advantage for the economy.

Other argument from the category of market failures is represented by the existence of dual economies, model elaborated by the American Arthur Lewis. According to this model, in the developing countries it is a labor surplus in agriculture, with a marginal productivity very low or even null. So, the entrepreneurs pay wages that outweigh the cost of work in agriculture and employ fewer workers than the optimum social necessary.

The American Event Hagen argued that a tariff may increase the industrial production and, thus, facilitate the labor transfer from agriculture with zero productivity to industry, providing a net social production gain.

The argument of dual economy is criticized as it doesn't take into account the positive productivity in agriculture during harvest and it ignores the cost of the transfer of rural population in towns. For these reasons, the economists do not agree unanimously with the empirical validity of dual economy model.

Finally, other argument is related to externalities. The purest case of market failure is when production or consumption affects population welfare, and the prices of goods do not reflect these benefits or external costs. In the case of positive external effects, the general social welfare may increase by the growth of domestic production, while the adverse external effects require the production decrease. The tariffs may be used to alter 
the domestic relative prices that would generate the rise or the fall of some merchandise production.

Recently, two arguments for the protections based on externalities are outstanding: the pollution and the export of profitable products for companies, but detrimental for the country terms of trade. The most relevant objection for the use of protection for the managing of externalities is that tariffs are insufficient, and a more direct intervention is preferable, such as the tax on pollution emissions (the case of pollution) or an export tax (the case of the terms of trade deterioration). [Krugman Paul, Obstfeld Maurice, 2006]

The social welfare function

The governmental sector has an important role in economy, mainly by the income redistribution and the providing of public services.

The effect of income redistribution caused by tariff has been pleaded by the Americans Paul Samuelson and Ronald Jones. They concluded that a tariff increases the relative income of the factor of production that is used intensively in the production of protected product. On other side, the American Lloyd Metzlar demonstrated that, the protection of a labor intensive product generates the decrease of its production and, thus, leads to smaller prices for labor, even that the country welfare maximized.

The best governmental policy (the first best solution) in the case of the decline of a certain industrial sector is to support the reallocation of the factors of production in rising competitive industries. Under these circumstances, the income redistribution does not take place. Nevertheless, if it is a per se aim, the redistribution should be done by fiscal and budgetary adequate policies, avoiding the use of second best solution, mainly commercial policy measures, such as tariffs.

In the first stages of economic development, the governments had few sources to collect revenues. In these conditions, the foreign trade sector tended to be one of the most important sources of state revenues. The use of tariffs as a revenue source causes conflicts with other objectives of tariff policy.

For example, if with a high tariff, the goal is to stop the imports, the customs collections would be zero. At the other extreme, in order to collect tariffs and custom fees may be necessary to impose a tariff for a product for which there is no reason for protection. Generally, the argument of using tariffs as a mean for realizing governmental revenues is reliable on if the social cost of obtaining revenues from any other is more difficult, such as it may be the situation in developing countries. [Feenstra Robert, Taylor Alan, 2007]

Economic instability

We suppose that in a country the labor is completely used, and the foreign trade is balanced. Also, we suppose that in the rest of the world, a depression or a very reach harvest produces temporary a decrease of import prices of that country. The country would benefit from the improvement of terms of trade and, so, there is no reason for governmental intervention.

But, analyzing realistic the situation, we can drop other conclusions. First, the improvement of terms of trade generates the decrease of its factors of production used intensely in the imported product. Secondly, the factors of productions affected would tend to move form import sectors into export sectors, but this stimulus will disappear simultaneous to the resettlement of the world prices at the previous level, that will determine them to come back in import sectors. 
In order to avoid costly perturbations from social point of view, in the analyzed situation, the tariff may be used a temporary measure. By putting up the price of imports, the factors involved intensively in the production of import products will stay stable in that sector.

From historic point of view, temporary tariffs have been used complementary or as a substitute for monetary and fiscal policies dedicated to maintain full employment.

\section{BIBLIOGRAPHY}

1. Feenstra Robert, Taylor Alan (2007) - International Economics, Worth Publishers, Incorporated Publishing House, New York;

2. Fota Constantin (2004) - Economie internațională, Scrisul Românesc Publishing House, Craiova;

3. Krugman Paul, Obstfeld Maurice (2006) - International Economics: Theory and Policy, Addison-Wesley Publishing House, Boston. 